\title{
Use of Puzzles as an Effective Teaching-Learning Method for Dental Undergraduates
}

International Journal of Clinical Pediatric Dentistry (2021): 10.5005/jp-journals-10005-2048

New DOI: 10.5005/jp-journals-10005-2048

Previous DOI-10.5005/jp-journals-10005-1834

Vol-13, issue-6

In this article we realized that Fig. 5, has incorrectly mentioned few headings in the graph.

\section{Correct Graph}

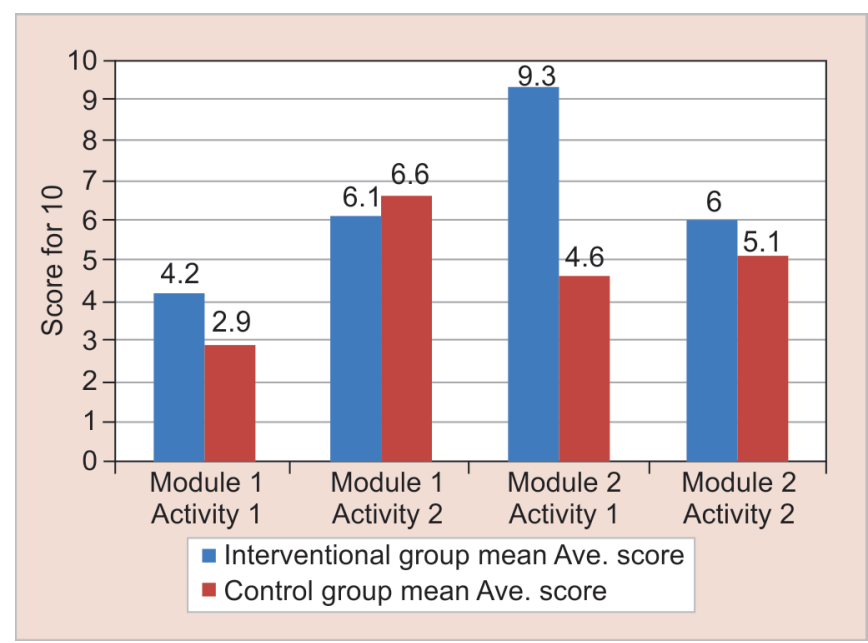

Fig. 5: Graphical representation of the mean scores of group I and group II. * $p<0.05$, Mann-Whitney test

\section{Incorrect Graph (That is Published)}

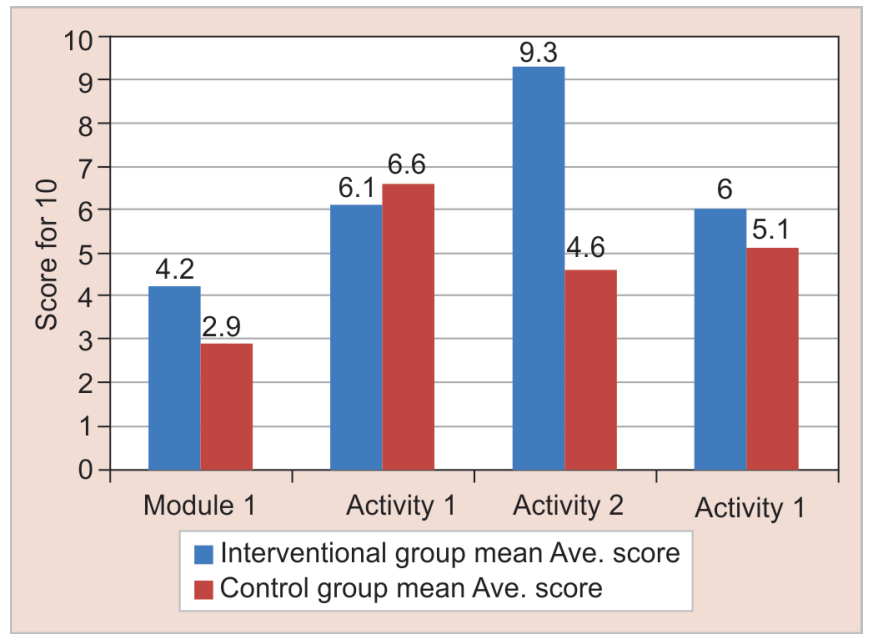

Fig. 5: Graphical representation of the mean scores of group I and group II. * $p<0.05$, Mann-Whitney test

() The Author(s). 2021 Open Access This article is distributed under the terms of the Creative Commons Attribution 4.0 International License (https://creativecommons. org/licenses/by-nc/4.0/), which permits unrestricted use, distribution, and non-commercial reproduction in any medium, provided you give appropriate credit to the original author(s) and the source, provide a link to the Creative Commons license, and indicate if changes were made. The Creative Commons Public Domain Dedication waiver (http://creativecommons.org/publicdomain/zero/1.0/) applies to the data made available in this article, unless otherwise stated. 